\title{
TRADITIONAL CHRISTIAN THEISM AND TRUTHMAKER MAXIMALISM
}

\section{TIMOTHY PAWL}

University of St. Thomas

\begin{abstract}
I argue that Traditional Christian Theism is inconsistent with the conjunction of Truthmaker Necessitation and Truthmaker Maximalism, the thesis that all truths have truthmakers. Though this original formulation requires extensive revision, the gist of the argument is as follows. Suppose for reductio Traditional Christian Theism and the sort of Truthmaker Theory that embraces Truthmaker Maximalism are both true. By Traditional Christian Theism, there is a world in which God, and only God, exists. There are no animals in such a world. Thus, it is true in such a world that there are no zebras. That there are no zebras must have a truthmaker, given Truthmaker Maximalism. God is the only existing object in such a world, and so God must be the truthmaker for this truth, given that it has a truthmaker. But truthmakers necessitate the truths they make true. So, for any world, at any time at which God exists, God makes that there are no zebras true. According to Traditional Christian Theism, God exists in our world. In our world, then, it is true: there are no zebras. But there are zebras. Contradiction! Thus, the conjunction of Traditional Christian Theism with Truthmaker Necessitation and Truthmaker Maximalism is inconsistent.
\end{abstract}

\section{INTRODUCTION}

In this paper I argue that Traditional Christian Theism is inconsistent with the thesis that all truths have truthmakers; that is, that Traditional Christian Theism is inconsistent with Truthmaker Maximalism. I will focus primarily on Traditional Christian Theism, since it is the type of theism with which I am most familiar. Later, however, I will provide 
some evidence to think that traditional versions of the other Abrahamic faiths are also inconsistent with Truthmaker Maximalism.

According to Traditional Christian Theism, God is the author of all that exists - all besides God, that is. Nothing exists without originating from God as its source. Furthermore, Traditional Christian Theism also affirms that God was under no compulsion to create; the divine might have created nothing at all. Creation, Traditional Christianity teaches, is a gratuitous act. These two claims together support this following third claim: that God might have existed without anything else. Put in another, though misleading, way, there is a possible world in which God, and only God, exists. (This claim is misleading precisely because it seems that a successful checklist of things existing in a world in which God exists would include at least two things: God, the world.)

According to Truthmaker Theory, truthmakers must necessitate the truth of the propositions they make true. ${ }^{1}$ That is, if an object, T, is a truthmaker for a proposition, $p$, then in any world, at any time at which T exists, $p$ must be true. ${ }^{2}$ If David Armstrong is a truthmaker for the truth, that David Armstrong exists, then, in any world, at any time at which David Armstrong exists, the proposition that David Armstrong exists is true. Furthermore, some adherents to Truthmaker Theory affirm Truthmaker Maximalism. In fact, there are those, friend and foe of Truthmaker Theory alike, who argue that a proponent of Truthmaker Theory should affirm Truthmaker Maximalism as well. ${ }^{3}$

In this paper I will argue that Traditional Christian Theism is inconsistent with the sort of Truthmaker Theory that embraces Truthmaker Maximalism. Though the fine-tuning of the argument will take some work, the gist of the argument goes as follows. Suppose Traditional Christian Theism and the sort of Truthmaker Theory that embraces Truthmaker Maximalism are both true. By Traditional

\footnotetext{
${ }^{1}$ Merricks claims, rightly, that "necessitarianism is now truthmaker orthodoxy". Trenton Merricks, Truth and Ontology (Oxford University Press, USA, 2009), pp. 5-8; David Malet Armstrong, Truth and Truthmakers (Cambridge University Press, 2004), pp. 5-6.

${ }^{2}$ In this paper, I will treat things that exist atemporally (possible examples include God and abstracta) as existing at all times for the purposes of necessitation.

${ }^{3}$ An example of a friend of Truthmaker Theory providing such arguments is Ross Cameron. See Ross P Cameron, "How to Be a Truthmaker Maximalist", Noûs 42, no. 3 (2008), 412-415.; an example of a foe is Trenton Merricks, who provides no fewer than four arguments that truthmaker theorists ought to be Truthmaker Maximalists. See Merricks, Truth and Ontology, pp. 23-27.
} 
Christian Theism, there is a world in which God, and only God, exists. ${ }^{4}$ There are no animals in such a world. For instance, there are no zebras in such a world. Thus, it is true in such a world that there are no zebras. That there are no zebras must have a truthmaker, given Truthmaker Maximalism. God is the only existing object in such a world, and so God must be the truthmaker for this truth, given that it has a truthmaker. ${ }^{5}$ But truthmakers necessitate the truths they make true. So, for any world, at any time at which God exists, God makes that there are no zebras true. According to Traditional Christian Theism, God exists in our world. In our world, then, it is true: there are no zebras. But there are zebras. Contradiction! Thus, the conjunction of Traditional Christian Theism with Truthmaker Necessitation and Truthmaker Maximalism is inconsistent. In the remainder of this paper, I will present the argument with more detail and consider objections to it.

\section{THE ARGUMENT IN DETAIL}

In this section I will argue that the conjunction of five theses - two from Traditional Christian Theism, two theses of a standard Truthmaker Theory, and one obvious empirical observation - together entail a contradiction. It is not my goal here to argue for the truth of these five theses. In the following section I will give some reason to think that the two theses I present from Traditional Christian Theism deserve the title (whether honorific or not) of being part of Traditional Christian Theism. Whether or not they, or the other three theses, are true is irrelevant to whether they are, jointly, inconsistent. Likewise, my choice of empirical observation - that there are zebras - is not important. If this paper is dug out from beneath the rubble in a post-apocalyptic, post-equestrian future, that reader may change the empirical observation to that there is

${ }^{4}$ Worlds containing only one being are sometimes called 'lonely worlds', since it is assumed that such a being would be lonely. Given Traditional Christian Theism, though, this is a misnomer. For, given the traditional view of the Godhead, combined with a common principle concerning when one has company and when one has a crowd, such a world is positively crowded with persons.

${ }^{5}$ For another truthmaker argument from lonely entities that aims at a different conclusion, see David Malet Armstrong, "Truthmakers for Negative Truths and for Truths of Mere Possibility", in Metaphysics and Truthmakers, ed. Jean-Maurice Monnoyer (Ontos Verlag, 2007), pp. 99-104. For a critical discussion of that argument, see Timothy Pawl, "The Possibility Principle and the Truthmakers for Modal Truths", Australasian Journal of Philosophy 88, no. 3 (2010), 417-428. 
rubble with my permission (and, also, my sympathies). The five jointly inconsistent theses are as follows:

The Universal Creation Necessarily, for any thing that exists that is not

Thesis: identical with God, God created that thing.

The Possible Non-

Necessarily, it is possible that God create nothing.

Creation Thesis:

Truthmaker

Necessarily, if T makes $p$ true, then, in any world,

Necessitation: at any time at which T exists, $p$ is true.

Truthmaker

Necessarily, every truth has a truthmaker.

Maximalism:

The Zebrine Thesis: $\quad$ In our actual world, at this time, zebras exist.

Consider the following argument, which I will call The Original Argument:

1. Suppose that the conjunction of the Universal Creation Thesis, the Possible Non-Creation Thesis, Truthmaker Necessitation, Truthmaker Maximalism and the Zebrine Thesis is true. (For reductio.)

2. There is a possible world at which only God exists; call it 'W'. (From the Universal Creation Thesis and the Possible Non-Creation Thesis.)

3. At $\mathrm{W}$, it is true that there are no zebras. (From 2.)

4. There is a truthmaker for that there are no zebras at W. (From Truthmaker Maximalism.)

5. God is the truthmaker for that there are no zebras at W. (From 2, 4.)

6. God necessitates the truth of that there are no zebras. (From Truthmaker Necessitation, 5.)

7. At any world, at any time at which God exists, it is true that there are no zebras. (From Truthmaker Necessitation, 6.)

8. It is true in the actual world, right now, that there are no zebras. (From, 7 and the assumption that God exists.)

9. Contradiction! (From the Zebrine Thesis, 8.)

10. The conjunction of the Universal Creation Thesis, the Possible Non-Creation Thesis, Truthmaker Necessitation, Truthmaker Maximalism and the Zebrine Thesis is false. (1-9)

Premise 2 is true, given the Universal Creation Thesis and the Possible Non-Creation Thesis. For, given the Universal Creation Thesis, the only possible way for something besides God to exist is for God to create it. So, in any world, if there exists a thing that is not God, that thing is created by God. Given the Possible Non-Creation Thesis, there is a world in 
which God does not create anything. In that world, then, nothing besides God exists. And so, given those two claims, there is a world where God and only God exists.

The step from Premise 2 to Premise 3 requires justification, since it seems to reify something or other that has a truth-value. But God is not something that has a truth-value. (Being the Way, the Truth, and the Life requires a truth-value in the same way it requires a way-value.) And so Premise 3 seems to require that there exist something that is not God. But such a claim contradicts Premise 2. This is a good point; I leave discussion of it until the next section of the paper, where I discuss objections to the argument.

Given that it is true that there are no zebras at W, and given Truthmaker Maximalism, something or other at W must make this claim true. Thus, Premise 4 is true. Since, given Premise 2, God alone exists at W, there is one and but one contender for the role of being the truthmaker for the claim that there are no zebras. That thing is God. And since, by Premise 4, there is a truthmaker for that there are no zebras, God is the truthmaker for that there are no zebras, as Premise 5 claims. Since Truthmakers necessitate the truths they make true, and God is the truthmaker for that there are no zebras, Premise 6 has it right: God necessitates the truth that there are no zebras.

But since God necessitates the truth that there are no zebras, any world and time where God exists is a world and time at which it is true that there are no zebras, as Premise 7 asserts. But then Premise 8 follows, since the Traditional Theist claims that God exists here and now - here and now it is true that there are no zebras. ${ }^{6}$ This premise, Premise 8 , contradicts the empirical truth that there are, in fact, zebras in the here and now. Thus, a contradiction has been derived. The initial set of propositions is inconsistent. A Traditional Christian Theist cannot consistently affirm both Truthmaker Necessitation and Truthmaker Maximalism.

In the following section I will consider objections to the Original Argument.

\section{OBJECTIONS AND REPLIES}

In this section I will discuss objections to the Original Argument. I see two main sorts of objections to an argument of this sort. One can object

\footnotetext{
${ }^{6}$ Recall that I am assuming that anything that exists atemporally in a world necessitates the truths that it makes true at all times in that world.
} 
in some way to the starting assumption for reductio, or one can object in some way to the inferences from those assumptions. Concerning the objections to the initial assumption, I will consider the following objections: that I have not aptly construed Traditional Christian Theism, that I can not accommodate the denials some contemporary Christian philosophers have made of the Universal Creation Thesis and the Possible Non-Creation Thesis, and that I have not aptly construed the necessitation requirement for truthmaker theories.

One objection to the Original Argument is that it misfires; even if it were sound, the Universal Creation Thesis and the Possible NonCreation Thesis are not parts of Traditional Christian Theism. And so, while it might show an inconsistency in believing those five theses, that particular conjunction of five theses does not include an apt portrayal of Traditional Christian Theism. In response I will give evidence for the claim that both theses are included in Traditional Christian Theism, as well as evidence to think that they might well be included in traditional versions of the other Abrahamic religions.

The Universal Creation Thesis at least appears to be affirmed by Traditional Christian Theism. For instance, very many Christian creeds claim that God is the author of all things. The Church Fathers at the first Ecumenical Council, the Council of Nicaea (A.D. 325), profess that the Father is all powerful and "maker of all things both seen and unseen"? Likewise, the Nicene Fathers also profess that it was through the Son that "all things came to be, both those in heaven and those in earth". ${ }^{8}$ The same is asserted at other Ecumenical Councils of the Christian Church, including the First Council of Constantinople (A.D. 381), the Council of Ephesus (A.D. 431), and the Council of Chalcedon (A.D. 451). ${ }^{9}$ The Universal Creation Thesis has been taught as a dogmatic truth by some Christian groups. Ludwig Ott claims, for instance, that it is a De Fide truth of the Catholic Faith that "All that exists outside God was, in its whole substance, produced out of nothing by God". ${ }^{10}$ Finally, paragons of

\footnotetext{
${ }^{7}$ Norman P. Tanner, Decrees of the Ecumenical Councils 2 Volume Set (Georgetown University Press, 1990), p. 5.

${ }^{8}$ Ibid.

${ }^{9}$ See Ibid., pp. 24, 64, and 84 respectively.

${ }^{10}$ Ludwig Ott, Fundamentals of Catholic Dogma (Tan Books and Publishers, 2009), p. 79.
} 
Traditional Christian Theism, for instance, Thomas Aquinas, affirm it in no unclear terms. ${ }^{11}$

Traditional versions of the other two Abrahamic Faiths seem to me to affirm The Universal Creation Thesis as well. For instance, the Quran teaches that "Allah is the Creator of all things, and He is, over all things, Disposer of affairs" and it also characterizes God as "He to whom belongs the dominion of the heavens and the earth and who has not taken a son and has not had a partner in dominion and has created each thing and determined it with [precise] determination". ${ }^{12}$ With respect to Judaism, in his Mishneh Torah (Basic Principles of the Torah), Maimonides states that:

The basic principle of all basic principles and the pillar of all sciences is to realize that there is a First Being who brought every existing thing into being. All existing things, whether celestial, terrestrial, or belonging to an intermediate class, exist only through his true existence. If it could be supposed that He did not exist, it would follow that nothing else could possibly exist $(1: 1-2) .^{13}$

Likewise, the Possible Non-Creation Thesis, too, has some lofty credentials as far as Traditional Christian Theism is concerned. The First Vatican Council (A.D. 1869-1870), affirming a common and long held view within the Christian tradition, taught that:

If anyone does not confess that the world and all things which are contained in it, both spiritual and material, were produced, according to their whole substance, out of nothing by God; or holds that God did not create by his will free from all necessity, but [says instead that God created] as necessarily as he necessarily loves himself... let him be anathema. ${ }^{14}$

The Church Fathers at Vatican 1 are claiming that it is free for God whether or not to perform a creative act at all, and not merely what sort

${ }^{11}$ See Thomas Aquinas, On The Power of God (Quxestiones disputatce de potentia Dei), trans. English Dominican Fathers (Burns Oates \& Washbourne Ltd, 1932), question 3, article 5 .

${ }^{12}$ The first quotation is from 39:62, the second from 25:2. Both translations are from the Sahih International Translation.

${ }^{13}$ Isadore Twersky, A Maimonides Reader, First Edition. (Behrman House, Inc., 1972), p. 43.

${ }^{14}$ The First Vatican Council, Session 3, the Canons on God the Creator of All Things, Canon 5, quoted from Tanner, Decrees of the Ecumenical Councils 2 Volume Set, p. 810. 
of creative act to perform. There was no necessity in his creating at all. Again, Ludwig Ott claims the following to be a dogmatic proposition for Catholics: "God created the world free from exterior compulsion and inner necessity. ${ }^{15}$ We find exemplars of Traditional Christian Theism affirming this proposition as well. ${ }^{16}$

Turning again to Judaism, Maimonides writes, immediately following the previous quotation from his Mishneh Torah:

If, however, it were supposed that all other beings were non-existent, $\mathrm{He}$ alone would still exist. Their non-existence would not involve His nonexistence. For all beings are in need of Him; but $\mathrm{He}$, blessed be $\mathrm{He}$, is not in need of them, nor any one of them (1:3). ${ }^{17}$

In fact, Maimonides puts both the Universal Creation Thesis and the Possible Non-Creation Thesis together in his Guide for the Perplexed, 2.13, when he writes:

...the opinion of all who believe in the Law of Moses our Master, peace be on him, is that the world as a whole - I mean to say, every existent other than God, may He be exalted - was brought into existence by God after having been purely and absolutely nonexistent, and that God, may He be exalted, had existed alone, and nothing else - neither an angel nor a sphere nor what subsists within the sphere. Afterwards, through His will and His volition, He brought into existence out of nothing all the beings as they are, time itself being one of the created things... ${ }^{18}$

Here Maimonides claims that God creates every other thing that exists, that he does so after existing alone in the world, and that this creation is due to God's volition and will (and not, presumably, due to compulsion).

It seems to me, then, that there is a good case to be made that Traditional Christian Theism affirms these two theses, and that Traditional Judaism does as well. ${ }^{19}$

${ }^{15}$ Ott, Fundamentals of Catholic Dogma, p. 83.

${ }^{16}$ Aquinas writes "I answer that without any doubt we must hold that God by the decree of his will and by no natural necessity brought creatures into being". He goes on to provide four arguments for this claim. See Aquinas, On The Power of God (Quoestiones disputatce de potentia Dei), question 3, article 15.

17 Twersky, A Maimonides Reader, pp. 43-44.

${ }^{18}$ As quoted in Sarah Pessin, "The Influence of Islamic Thought on Maimonides", sec. 2. Cosmos, Creation, Emanation, URL $=<$ http://plato.stanford.edu/entries/ maimonides-islamic/\#CosCreEma>, accessed Aug 30, 2011.

${ }^{19}$ A Muslim colleague of mine in a Theology Department whose specialty is Islamic theology informs me that Islam also affirms both of these theses, but I have not been 
A second objection stems from the fact that religiously inclined philosophers of religion deny these claims. Whatever their proud pedigree might be, both of these theses have been denied in print by a philosopher in the last decade. This denial is surely no reason to think the argument is faulty. However, all things being equal, it would be better to employ premises acceptable to more rather than fewer religiously inclined philosophers of religion.

For instance, Peter van Inwagen denies the Universal Creation Thesis. He believes that there are abstracta (for instance, propositions, properties and numbers), and that God is not the creator of abstracta, owing to the fact that abstracta are not the sort of thing that can fall under a causal relation, and creation is a causal relation..$^{20}$ Van Inwagen reads the propositions from the Ecumenical Councils cited earlier as tacitly restricted to creatable things. Since abstracta are not creatable, the Church Fathers did not have them in mind. ${ }^{21}$

Norman Kretzmann denies the Possible Non-Creation Thesis. He concludes a discussion of whether God must create with the following line: "As I see it, then, God's will is necessitated as regards whether to create, but fully free as regards what to create."22 In the following I will consider whether I can accommodate these two denials.

I can accommodate van Inwagen by weakening the Universal Creation Thesis. To do so, I can claim that God is the author of all contingent beings, leaving it unstated whether there are other necessary beings and

able to find as explicit an endorsement for them from Islam as I have from the other two Abrahamic faiths.

${ }^{20}$ Peter van Inwagen, "God and Other Uncreated Things", in Metaphysics and God: Essays in Honor of Eleonore Stump, ed. Kevin Timpe (New York: Routledge, 2009), pp. 3-20, for a summary of his position and reasoning, see the final two paragraphs on p. 20.

${ }^{21}$ To be fair to van Inwagen, there is some corroborating evidence for this sort of reading from some sources of Traditional Christian Theism. For instance, the Fourth Lateran Council (A.D. 1215) says God is "one principle of all things, creator of all things invisible and visible, spiritual and corporeal; who by his almighty power at the beginning of time created from nothing both spiritual and corporeal creatures, that is to say angelic and earthly..." This quotation seems to gloss 'invisible and visible' as meaning 'spiritual and corporeal,' then gloss 'spiritual and corporeal' as meaning 'angelic and earthly.' Since abstracta, if there are such things, are neither angelic nor earthly, it seems that affirming that God did not create abstracta might not go afoul of the affirmation that God created all visible and invisible things.

${ }^{22}$ Norman Kretzmann, The Metaphysics of Theism: Aquinas's Natural Theology in Summa Contra Gentiles I (Oxford University Press, USA, 2002), p. 225. 
whether God created them if there are some. Call this new thesis the Contingent Creation Thesis:

The Contingent Creation Thesis: Necessarily, for any thing that is contingent, God created that thing. ${ }^{23}$

All those who affirm the Universal Creation Thesis will grant the Contingent Creation Thesis, since it is straightforwardly logically entailed by the Universal Creation Thesis. Furthermore, those who do not grant the Universal Creation Thesis for the sorts of reasons van Inwagen gives can, nevertheless, grant the Contingent Creation Thesis. So the modification loses no adherents and gains additional adherents.

The move to the Contingent Creation Thesis has other worries, though. For one, it saves the argument from this objection by providing a response that, if affirmed, falsifies the second premise. That is because if abstracta such as the proposition that there are zebras exist in $\mathrm{W}$, it is false that God and God alone exists in W, as Premise 2 states. So Premise 2 must be reworded for those who resort to the Contingent Creation Thesis. The rewording is not harmful to the thrust of the argument, though. Rather than say that W contains God and God alone, we must say, instead, in the revised version of Premise 2, that at W only God and other necessary beings (if there are such things) exist. Similar amendments are required for Premises 5-7 as well. One might worry that these amendments render the argument unsound.

One might worry here that allowing other necessary beings besides God into the picture might allow for other truthmakers besides God, and so ruin the argument. The argument would be ruined since the inference from Premise 4 to Premise 5 would be invalid. It would be invalid

${ }^{23}$ This statement of the Contingent Creation Thesis entails that God is not contingent, since, were God contingent, he would have to create himself by this thesis, and it is impossible for a thing to create itself. While I believe it to be part of Traditional Christian Theism that God is not contingent, I will note that some contemporary Christian philosophers think that God is logically contingent. Richard Swinburne, for instance, gives two arguments that God is contingent. First, because it is conceivable that there be a complex physical universe but not God, and conceivability is some guide to possibility; second, because that which is logically necessary cannot explain that which is logically contingent, and so God couldn't explain the existence of the universe, were God necessary. See Richard Swinburne, The Existence of God, 2nd ed. (Oxford University Press, USA, 2004), p. 148. Also see Richard Swinburne, Is God Necessary, Closer To Truth, $\mathrm{URL}=<\mathrm{http}$ //www.closertotruth.com/video-profile/Is-God-Necessary-RichardSwinburne-/249>, accessed August 24, 2011. 
because, were there really other entities besides God in the world, then we would not be able to infer that God is the truthmaker for that there are no zebras from the claim that something or other is the truthmaker.

My reply to this objection is twofold: (i) allowing the possibility of other logically necessary beings besides God does allow for the possibility of other potential truthmakers, but (ii) this poses no problem for the forthcoming considered form of the argument. Additional necessary entities pose no problem for the considered form of the argument because, given Truthmaker Necessitation, no necessary being can be a truthmaker for a contingent truth.

To see that, given Truthmaker Necessitation, no necessary being can be a truthmaker for a contingent truth, suppose, for reductio, that it is possible for some necessary being, call it $\mathrm{N}$, to be a truthmaker for some contingent truth, call it $C$. Since $\mathrm{N}$ is a truthmaker for $C$, in any world, at any time at which $\mathrm{N}$ exists, $C$ will be true (given Truthmaker Necessitation). But $\mathrm{N}$ exists in all worlds at all times, and so $C$ must be true in all worlds at all times. $C$, though, is contingent. So, in at least one world, at at least one time, $C$ is false. So, in at least one world, at at least one time, $\mathrm{C}$ is both true and false. But that is impossible. Thus, to conclude the reductio, it is not possible for a necessary being to be a truthmaker for a contingent truth. An exactly parallel argument can be run showing that any grouping of necessary beings cannot be a truthmaker for a contingent truth. This leads to a conclusion worthy of italics: If Truthmaker Necessitation is true, then no necessary being can be a truthmaker for a contingent truth.

No matter how many other necessary entities we add to the world, then, none of them, either singularly or grouped, will be a truthmaker for a contingent truth. And since that there are no zebras is a contingent truth (it is true in W, but false in our world), it does not matter whether we start with a world containing one being - God - or a world containing an infinite number of beings, given that all the beings in question are necessary. While the language of some premises will have to be changed (for instance, Premise 2 will have to say that there is a world with only necessary things, rather than only God), this change will still allow the derivation of the inconsistency between Traditional Christian Theism and Truthmaker Theory conjoined with Truthmaker Maximalism. Given that it does all the work I need it to do and it is weaker than the more robust Universal Creation Thesis, in the forthcoming, considered argument, I will use the Contingent Creation Thesis. 
Whether or not I am able to accommodate Kretzmann's views on the Possible Non-Creation Thesis depends upon how radical God's freedom is. Kretzmann claims that God is 'fully free' to create whatever he chooses. Either this full freedom allows for the creation of a single contingent entity, say, just a single electron (and its contingent constituents, for instance, that thing's tropes, if there are such things), or it does not. What follows is a proof by cases.

Suppose one thinks that God's full freedom is radical freedom to create a single contingent entity (again, and its contingent constituents, if there are such things). The following seems possible. Prior to creation, God peruses all the feasible possible worlds. His gaze alights on the possible world that would be actualized, were this creation which we inhabit created. Call that possible world W1. Within W1 he focuses on one particular entity that would exist simultaneously with your reading of this paper, were W1 actualized, say, electron E. He decrees, "let there be a creation which contains all and only one contingent entity (and its contingent constituents, if such there be): E." Such a creation comes into existence. In such a creation, it is true that there are no zebras. But neither the necessary inhabitants of that world nor E make it true that there are no zebras. I've already presented the argument for why the necessary inhabitants do not make the contingent truth, that there are no zebras, true. E doesn't make it true either.

Suppose, for reductio, that it were possible that E make it true that there are no zebras. Given Truthmaker Necessitation, in any world, at any time E exists, it is true that there are no zebras. However, E exists in the actual world now. And so it is now true that there are no zebras. But there are zebras now. And so we have reached a contradiction. In the world I am envisioning, the world containing only necessary beings and $\mathrm{E}$, neither the necessary beings nor the lone contingent thing is a truthmaker for that there are no zebras. And so that truth has no truthmaker. But this contradicts Truthmaker Maximalism. So if Kretzmann takes God to be fully free in this radical sense (call this the Radical Freedom Thesis), then I could run the argument from God's radical freedom without reference to the Possible Non-Creation Thesis. Even if the Possible Non-Creation Thesis were false, if it is possible that God creates all and only E (plus, for the last time, any contingent constituents of E), then the Radical Freedom Thesis and the Contingent Creation Thesis together preclude the conjunction of Truthmaker Necessitation and Truthmaker Maximalism. 
Suppose, for the other case, that God's freedom is not radical in this sense. Then I might not be able to accommodate Kretzmann. For it might be that while God is free to choose between possible creations, each possible creation might include something that is a truthmaker for negative existentials. For instance, perhaps God must create some totality state of affairs or other, though he is free to pick which one he creates. In such a case, that totality state of affairs could be the truthmaker for negative existentials, and so there could be a truthmaker for each negative existential in such a world. ${ }^{24}$ Or perhaps God must create some world or other, even if that world is vacant. (God can build the warehouse but fill it with no wares.) In such a case, the world could be the truthmaker for negative existentials, and so there could be a truthmaker for each negative existential in such a world. ${ }^{25}$ In either case, there would be a truthmaker for negative existentials, call it The Solution. In this, our actual world, The Solution could not exist now, seeing as we have zebras in our world now, and the existence of The Solution precludes the truth of the proposition that there are zebras. And so, Premise 8 would lack justification, and the contradiction reached at Premise 9 would as well. In short, given that God is free to create whatever he wants, so long as it includes a Solution, my argument fails.

Thus, depending on the extent of God's full freedom, I may or may not be able to accommodate Kretzmann's claim. The freer God is, the better chance I have at accommodation. Radical freedom, as I have called it, allows for an argument parallel to my own to show that Traditional Christian Theism and the sort of Truthmaker Theory that embraces Truthmaker Maximalism are inconsistent. Less radical freedoms must be dealt with on a case-by-case basis.

A final objection to the initial assumption for reductio is that I have mischaracterized the necessitation that truthmaker theories require. I have claimed that if T makes $p$ true, then, in any world, at any time at which T exists, $p$ is true. This objector claims that, rather than Truthmaker Necessitation, I should have instead used:

Conditional Necessitation: Necessarily, if T makes $p$ true, then, in any world, at any time at which T exists and $p$ exists, $p$ is true.

${ }^{24}$ This is Armstrong's view of truthmakers for negative truths. See Armstrong, Truth and Truthmakers, chap. 5-6, especially Section 6.2.

${ }^{25}$ This is Cameron's view of truthmakers for negative truths. See Cameron, "How to Be a Truthmaker Maximalist”, pp. 413-417. 
If I use Conditional Necessitation in my argument, rather than Truthmaker Necessitation, the argument fails. It fails because the step from Premise 2 to Premise 3 assumes that there is something there to be true or false, namely, the proposition that there are no zebras. But, this does not follow from Premise 2. From Premise 2 it follows that there are no zebras in that world, but it does not follow that there is a proposition, that there are no zebras, that has a truth-value. Likewise, Premise 7 is false as well, since there could be worlds where God exists but the proposition that there are no zebras does not, and so does not have a truth-value. ${ }^{26}$

In what follows, I will argue that one can start with the assumption of Conditional Necessitation rather than Truthmaker Necessitation and still derive the inconsistency between Traditional Christian Theism and Truthmaker Maximalism. Consider a proof by cases. Either propositions exist necessarily or they do not.

If they exist necessarily, then Conditional Necessitation will collapse back into Truthmaker Necessitation. ${ }^{27}$ Conditional Necessitation collapses back into Truthmaker Necessitation in such a case because the added conjunct in Conditional Necessitation, that the proposition in question exist, will be satisfied in every world. So in no world will Conditional Necessitation and Truthmaker Necessitation disagree. And so the move to Conditional Necessitation rather than Truthmaker Necessitation will not do any work for the objector, if propositions are necessary entities.

If propositions do not exist necessarily, then they are created by God, by the Contingent Creation Thesis. Consider a world where God creates all and only the proposition that there are no zebras. In such a world, both that there are no zebras and God exist. That there are no zebras is true. Given Truthmaker Maximalism, it must have a truthmaker. I have argued that God, since he is necessary, cannot be a truthmaker for this contingent truth. But the proposition cannot make itself true, either. For one thing, no truthmaker for $p$ can coexist with a truthmaker for $\sim p$. But the proposition that there are no zebras can coexist with a zebra, and a zebra is a truthmaker for that it is not the case that there are no zebras. (Witness our own world where both that there are no zebras and at least one zebra coexist.) And so that there are no zebras is not a truthmaker for itself. Furthermore any proposition at all could coexist with a zebra. So

\footnotetext{
${ }^{26}$ My thanks to Jonathan D. Jacobs for pressing me on this point.

${ }^{27}$ Merricks makes this point as well; see Merricks, Truth and Ontology, pp. 10-11.
} 
even if God created every possible proposition in the world in question, there still wouldn't be a truthmaker for that there are no zebras in such a world. So, there is no viable candidate truthmaker for that there are no zebras in the world in question. And so we have here a counterexample to Truthmaker Maximalism.

Thus, whether truthbearers are necessary or whether they are contingent, the move to Conditional Necessitation does not alleviate the inconsistency between Traditional Christian Theism and the sort of Truthmaker Theory that affirms Truthmaker Maximalism.

This concludes the objections to the assumption made for reductio. The remaining objections are objections to the inferences made in the argument.

I referred to this first objection in the previous section's discussion of Premise 3. One might object: If there is a world where only God exists, as Premise 2 has it, then in that world, there would be no thoughts, statements, propositions, or anything else that can be true or false. So there is no thought, statement, or proposition, that there are no zebras in such a world. And so there wouldn't be such a thought, statement, or proposition to be true in such a world. And so it is not true that, at the God-only world, that there are no zebras is true. That is, on this objection, Premise 3 is false.

The move to the Contingent Creation Thesis protects against this objection. It does so because the proponent of my argument could allow the existence of non-contingent propositions in that world (as van Inwagen would). If propositions are necessary abstracta, then the proposition that there are no zebras exists in that world (and every other world) to be true or false.

The proponent of the Universal Creation Thesis will need another response to this objection, since she will deny that propositions necessarily coexist with God. But then the proponent of the Universal Creation Thesis will already realize that she needs an idiosyncratic account of truth and knowing, since, given that God knows anything at all in a world where God doesn't create, God's knowing truth does not require the existence of some thing, a truth, that is known. Given that in the God-only world God knows, for example, that God exists, such knowing is nothing at all, or nothing other than God. The proponent of the Universal Creation Thesis is encouraged to provide her own favourite 
response to the question of how at least some of God's contingent knowledge does not require the existence of any other entities. ${ }^{28}$

Another response to this objection stems from the proof by cases I gave to show that Conditional Necessitation leads to the inconsistency between Traditional Christian Theism and Truthmaker Maximalism. For that proof by cases did not make use of a God-only world. Rather, it began with a world where God and the proposition that there are no zebras both exist and still concluded that, in such a world, that there are no zebras would lack a truthmaker.

Another objection might go as follows: suppose that it is true that there could be a world in which only God and other non-created objects exist. The previous objection argued there would not be any truth in the world postulated for Premise 2 of the Original Argument, owing to the lack of things to be true in that world. That objection was answered in one way by retreating to the weaker Contingent Creation Thesis, since such a thesis allows there to be uncreated propositions that can be true or false in W. But there is still a worry in the neighbourhood. Even if a world filled with only non-created, necessary beings is one where there are things that can have truth-values (e.g., propositions), such a world would lack their being true. That is, such a world would lack whatever ontological story we tell to explain how it is that propositions are true. For instance, in such a world, there would be no contingent property instantiations. But if truth is a property, and that there are no zebras instantiates the property of truth contingently, then that there are no zebras could not be true if there were no contingent entities. Similar reasoning shows that if the ontological explanation for what it is for a proposition to be true includes a contingent thing of any sort (an event, a property exemplification, a trope, a real relation, a state of affairs, etc.), then no contingent proposition would be true in W. And so Premise 3 is false: it is not true at $\mathrm{W}$ that there are no zebras. The contradiction does not follow; the argument is unsound; the inconsistency is not shown.

This objection depends upon a theory of truth that is inconsistent with the conjunction of the Contingent Creation Thesis, the Possible Non-Creation Thesis, and the claim that God knows his own actions

${ }^{28}$ For an example of a response see Thomas Aquinas, The Disputed Questions on Truth (in three volumes), trans. Robert Schmidt (Chicago: Henry Regnery Co., 1954), question 2; question 3, article 2. See also Thomas D Sullivan, "Omniscience, Immutability, and the Divine Mode of Knowing”, Faith and Philosophy (1991), pp. 21-35. 
(or lack thereof). ${ }^{29}$ For, since his actions are contingent (he might not have created, given the Possible Non-Creation Thesis), God's knowing his own actions entails God's knowing a contingent truth, even if he creates nothing. In such a world, he knows he did not create, though he could have. And so, in such a world, contrary to the objection at hand, there are contingent truths. So this objection to the Original Argument begins with an assumption that renders at least one of the theological presuppositions of Traditional Christian Theism false. As such, it is not an argument against the claims of inconsistency I've made against the conjunction of Traditional Theism and Maximalist Truthmaker Theory.

A third objection to the inferences in the Original Argument is that, while God is the truthmaker in W for the truth that there are no zebras, it isn't God all by himself that is the truthmaker. Rather it is some way that God is that is the truthmaker. God isn't that way in our world. (How could he be, with all these zebras running around?) So Premise 7 is false; it isn't true that at any world where God exists, it is true that there are no zebras.

To this objection, I reply that it either denies Conditional Necessitation or it denies the Possible Non-Creation Thesis. For Conditional Necessitation requires that there be a thing that, whenever or wherever it coexists with the relevant proposition, makes the proposition in question true. By its mere existence it makes the proposition true, and it couldn't do otherwise. Now, in this case, the case where only necessary things exist and it is something special about God, and not God all by himself, that makes it true that there are no zebras, what is the way that God is that the objector puts forward as the truthmaker for that truth? It cannot be all and only God by himself. For it if were all and only God, then it would be true in this world that there are no zebras, owing to the fact that God and the relevant proposition both exist in this world and Conditional Necessitation is true. So the truthmaker has to be God and something else. But what is the something else? If it were a necessary something else, then the same problem arises: God and that necessary something else coexist in this world, along with the proposition in question, and so it is true in this world that there are no zebras (again, given Conditional Necessitation). So it must be God and something contingent - perhaps the

${ }^{29}$ Traditional Theists typically claim something much stronger; that God is essentially omniscient. All I need for my purposes in this paragraph, though, is that in each world he knows at least one contingent thing. For simplicity's sake, in the forthcoming argument I will refer to God's actions rather than his actions or lack thereof. 
contingent way that God is. But then the objector has denied the truth of the Possible Non-Creation Thesis. The objector is saying that at the world where God creates nothing, and so nothing contingent exists, there is this contingent thing, a way that God is. Denying one or more conjuncts of a conjunction assumed for reductio is not a particularly impressive form of response to a reductio. (I say: "assume for the sake of argument that these five theses are true"; the objector responds: "no.") Thus, this objection either relies on a denial of Conditional Necessitation by allowing the very same thing (God) to make a proposition true in one world where that proposition exists but not make it true in another world in which it exists, or it relies on a denial of the Possible Non-Creation Thesis.

A final objection goes as follows: for any world, there might be no truths about entities or types of entities that do not exist in that world. Consider the claim that Alvin Plantinga calls 'Existentialism': "quidditative properties and singular propositions are ontologically dependent upon the individuals they involve." ${ }^{30}$ If Existentialism were true, there would be no propositions about zebras in a zebra-less world, since such propositions ontologically depend upon the things they involve - zebras - and there are no such things. And so, in W, it will not be true that there are no zebras. ${ }^{31}$ Furthermore, if Existentialism were true, there could be no world at which God creates all and only the proposition that there are no zebras, since there could not be such a proposition without a zebra. Thus, if Existentialism were true, the Original Argument's third premise would be false, since the proposition that there are no zebras would not be true in that world. And, in addition, my argument that one could start from Conditional Necessitation and show that Traditional Christian Theism is inconsistent with Truthmaker Maximalism is also unsound, since that argument required that God and that there are no zebras coexist in a world without zebras. Thus, were Existentialism true, my arguments for the inconsistency of Traditional Christian Theism and Truthmaker Maximalism would be unsound.

In response to this objection, I respond with a proof by cases. Either God knows by knowing propositions, or he knows in a sui generis way that does not require propositions but still requires truthmakers, or finally, he knows in a sui generis way that neither requires propositions nor truthmakers. I argue that the first two cases entail that Traditional

\footnotetext{
${ }^{30}$ Alvin Plantinga, “On Existentialism,” Philosophical Studies 44, no. 1 (1983), 3.

${ }^{31}$ I thank Jonathan D. Jacobs for pressing this point.
} 
Christian Theism and Truthmaker Maximalism are inconsistent, and the final case must be developed more to show that my argument is unsound.

Consider the first case. If God knows as we know, by knowing propositions, then Existentialism is inconsistent with Traditional Christian Theism. According to Traditional Christian Theism, God is not ignorant about the scope of God's own power. And God has the same creative power in all worlds. (God is no wimpier in $\mathrm{W}$ than he is in $\mathrm{W}^{*}$.) But, if Existentialism were true and God knows by knowing propositions, God would be ignorant, in at least some worlds, of the full extent of his creative power. For, in some worlds, there are no zebras. And in those worlds, there will be no truths about zebras. So it will not be true, in those worlds, that God can make zebras. Knowledge requires truth, though. So, in those worlds, given that God knows by knowing propositions, God cannot know that he can make zebras. And the same goes for any other sort of thing. In a world where God does not make anything, God won't even know that God can create creatures, since, in such a world, there are no creatures, and so no truths involving creatures.

Traditional theists will deny that God is ignorant of the limits of his creative powers, and will also deny that it is possible that God be wholly ignorant of the scope of his creative powers. And so, given that God knows by knowing propositions, Traditional Theists will have reason to deny Existentialism, the claim that there are no truths about entities in worlds without those entities. ${ }^{32}$

Consider the second case. Suppose that God knows in a sui generis way that does not require propositions but still requires truthmakers. Given Truthmaker Maximalism, there will still need to be something that makes God's belief that there are no zebras true (though the truthmaker will be making something besides a proposition true in this case). Given the Possible Non-Creation Thesis, there will still be a world where only necessary beings exist, and so there will be nothing fit to make the contingent truth that no zebras exist true in that world. Thus, if God knows in a way that doesn't involve propositions, but still requires truthmakers, then Existentialism does not render my argument unsound. Even if there were no propositions about zebras in a world without zebras, God would still know in his sui generis way of knowing

${ }^{32}$ For a defence of a sort of Theistic Existentialism, see Mark Ian Thomas Robson, Ontology and Providence in Creation: Taking ex nihilo Seriously (Continuum, 2008), pp. 72,130 . 
both that he could make zebras, and also that there are no zebras. And since, on assumption here, God's knowledge requires truthmakers, there would still have to be a truthmaker for this (non-propositional) truth.

Consider the third case. If God knows in a way that doesn't involve propositions and also doesn't require truthmakers, then I am less sure what to say. We would need to hear more about this sort of knowledge before we could assess whether it is coherent, and also whether it renders my argument unsound. Thus, I conclude that both the first cases leave my argument untouched, and this third case lacks sufficient detail to offer an actual threat to my argument.

This concludes the objections to the Original Argument. In the next, and final, section of this paper, I will present my considered argument, taking the objections I have raised in this section into account.

\section{THE CONSIDERED ARGUMENT}

With the objections answered, and with insights gleaned from the answering, I can now give my considered form of the argument.

Suppose the Contingent Creation Thesis and the Possible NonCreation Thesis are both true, as well as Conditional Necessitation and Truthmaker Maximalism. Either truthbearers exist necessarily or they exist contingently.

If truthbearers exist necessarily, then Conditional Necessitation collapses back into Truthmaker Necessitation, and the argument runs as follows. No necessary entity can be a truthmaker for a contingent truth. But there is a world where no contingent entities exist (by the Contingent Creation Thesis and the Possible Non-Creation Thesis). In such a world, it is true that there are no zebras, and this is a contingent truth. So nothing in that world can be a truthmaker for that truth (since everything that exists in that world is a necessary entity). So that truth, in that world, lacks a truthmaker. And so Truthmaker Maximalism is false, given the supposition made for reductio, along with the claim that truthbearers are necessary entities.

Suppose, then, that truthbearers are contingent entities. Consider a world where God makes truthbearers, but nothing else. In that world, that there are no zebras exists. Furthermore, it is true. It has a truthmaker, given Truthmaker Maximalism. What is that truthmaker? Either something necessary or something contingent. No necessary being can 
be the truthmaker, since then that there are no zebras would be true in all worlds in which it and that necessary being exist (given Conditional Necessitation). But that proposition and the necessary being (whatever it is) both exist in our world, so that there are no zebras would be true in our world. But, by the Zebrine Thesis, it is not true in our world that there are no zebras. So something contingent has to be the truthmaker for that there are no zebras. But the only contingent things in that world are propositions. No proposition is a truthmaker for that there are no zebras, though. For, it is possible for any proposition to coexist with a zebra. But it is impossible for a zebra to coexist with a truthmaker for that there are no zebras. And so none of the necessary nor contingent denizens of that world is a truthmaker for the proposition that there are no zebras. Thus, that there are no zebras lacks a truthmaker in that world. But this violates Truthmaker Maximalism. And so Truthmaker Maximalism is false, given the supposition made for reductio, along with the claim that truthbearers are contingent entities.

So, whether truthbearers are contingent or necessary, in a world that includes only God and propositions (and other necessary beings, if there are such things), the proposition that there are no zebras, while true, lacks a truthmaker. And so we've reached a contradiction. Whether or not truthbearers are contingent entities, Truthmaker Maximalism is false, given Traditional Christian Theism and Conditional Necessitation. And so our starting conjunctive assumption must be false. Traditional Christian theism is not consistent with Conditional Necessitation and Truthmaker Maximalism. ${ }^{33}$

\section{BIBLIOGRAPHY}

Aquinas, Thomas. On The Power of God (Qucestiones disputatoe de potentia Dei), translated by English Dominican Fathers (Burns Oates \& Washbourne Ltd, 1932) Aquinas, Thomas. The Disputed Questions on Truth (in three volumes), translated by Robert Schmidt (Chicago: Henry Regnery Co., 1954)

Armstrong, David Malet. Truth and Truthmakers (Cambridge: Cambridge University Press, 2004)

${ }^{33}$ I thank W. Matthews Grant, Jonathan D. Jacobs, Faith Glavey Pawl, Alexander Pruss, Bradley Rettler, Michael Rota, and Alexander Skiles for helpful discussions concerning this paper. I thank Aaron Segal for his help in tracking down the citations I give from Maimonides in the early part of this paper, and for helping me understand (to the extent that I do) Jewish views on the questions raised in this paper. 
Armstrong, David Malet. "Truthmakers for Negative Truths and for Truths of Mere Possibility", in Metaphysics and Truthmakers, edited by Jean-Maurice Monnoyer, pp. 99-104 (Ontos Verlag, 2007)

Cameron, Ross P. "How to Be a Truthmaker Maximalist", Noûs 42, no. 3 (2008), 410-421

Van Inwagen, Peter. "God and Other Uncreated Things", in Metaphysics and God: Essays in Honor of Eleonore Stump, edited by Kevin Timpe, pp. 3-20 (New York: Routledge, 2009)

Kretzmann, Norman. The Metaphysics of Theism: Aquinas's Natural Theology in Summa Contra Gentiles I (Oxford University Press, USA, 2002)

Merricks, Trenton. Truth and Ontology (Oxford University Press, USA, 2009)

Ott, Ludwig. Fundamentals of Catholic Dogma (Tan Books and Publishers, 2009)

Pawl, Timothy. "The Possibility Principle and the Truthmakers for Modal Truths", Australasian Journal of Philosophy 88, no. 3 (2010), 417-428

Pessin, Sarah. "The Influence of Islamic Thought on Maimonides", URL = $<$ http://plato.stanford.edu/entries/maimonides-islamic/\#CosCreEma $>$.

Plantinga, Alvin. "On Existentialism", Philosophical Studies 44, no. 1 (1983), 1-20.

Robson, Mark Ian Thomas. Ontology and Providence in Creation: Taking ex nihilo Seriously (Continuum, 2008)

Sullivan, Thomas D. "Omniscience, Immutability, and the Divine Mode of Knowing", Faith and Philosophy (1991), pp. 21-35

Swinburne, Richard. Is God Necessary. Closer To Truth, URL $=<$ http://www. closertotruth.com/video-profile/Is-God-Necessary-Richard-Swinburne-/249>.

Swinburne, Richard. The Existence of God. 2nd ed. (Oxford University Press, USA, 2004)

Tanner, Norman P. Decrees of the Ecumenical Councils 2 Volume Set (Georgetown University Press, 1990)

Twersky, Isadore. A Maimonides Reader. First Edition (Behrman House, Inc., 1972) 